\author{
Marquette University \\ e-Publications@Marquette
}

College of Communication Faculty Research

and Publications

Communication, College of

$6-27-2020$

\title{
Exploring the Effects of Different Online Syllabus Formats on Student Engagement and Course-Taking Intentions
}

Young Kim

Marquette University, young.kim@marquette.edu

Daradirek Ekachai

Marquette University, daradirek.ekachai@marquette.edu

Follow this and additional works at: https://epublications.marquette.edu/comm_fac

Part of the Communication Commons

\section{Recommended Citation}

Kim, Young and Ekachai, Daradirek, "Exploring the Effects of Different Online Syllabus Formats on Student Engagement and Course-Taking Intentions" (2020). College of Communication Faculty Research and Publications. 540.

https://epublications.marquette.edu/comm_fac/540 
Marquette University

e-Publications@Marquette

\section{Communications Studies Faculty Research and Publications/College of} Communication

This paper is NOT THE PUBLISHED VERSION; but the author's final, peer-reviewed manuscript. The published version may be accessed by following the link in the citation below.

College Teaching, Vol. 68, No. 4 (2020): 176-186. DOI. This article is @ Routledge, Taylor \& Francis and permission has been granted for this version to appear in e-Publications@Marquette. Routledge, Taylor \& Francis does not grant permission for this article to be further copied/distributed or hosted elsewhere without the express permission from Routledge, Taylor \& Francis.

\section{Exploring the Effects of Different Online Syllabus Formats on Student Engagement and Course-Taking Intentions}

\section{Young Kim}

Department of Strategic Communication, J. William and Mary Diederich College of Communication, Marquette University, Milwaukee, WI

Daradirek "Gee" Ekachai

Department of Strategic Communication, J. William and Mary Diederich College of Communication, Marquette University, Milwaukee, WI

\section{Abstract}

This study explores how different online syllabus formats affect students' engagement and their course-taking intentions. Using a 2 (format: online learning management system vs. instructor's website) X 2 (information amount: more vs. less) between-subjects design, an experimental study was 
conducted with undergraduate students at a large university in the United States Midwest to examine the effects of online syllabus format. This study found that students who read the instructor's website syllabus were more likely to engage with and take the course than students who received the syllabus through an online learning management system. Theoretical and practical implications are discussed.

\section{Keywords:}

Course syllabus, online syllabus, student engagement, course-taking intentions

\section{Introduction}

The COVID-19 pandemic has forced faculty to a sudden transition to online, remote teaching environment in the spring semester. With the public health crisis still in flux, some universities have planned to teach most classes virtually in the next semesters (Agrawal 2020). While some may contend that the pandemic could change education delivery forever, it seems the efficacy of online instruction is needed more than ever. A creation of an effective online syllabus could be a good start to help students navigate the course better and engage more remotely. This study explores how different online syllabus formats affect students' engagement and their course-taking intentions.

Before a new semester starts, college instructors normally spend some hours creating or updating their syllabi. Bart (2011) cited a report by the Syllabus Institute revealing that, on average, instructors spend 6.5 hours updating their syllabus for a new semester and nearly 3.5 hours maintaining their syllabus throughout a semester. For a new course, instructors spent more time creating a new syllabusaround 24 hours. With that much time invested, how can faculty make sure their syllabi will be interesting enough to engage students more?

Typically seen as a contract between an instructor and the students concerning the objectives and the overall plan of the course, a syllabus could engage with communication to students, and professors should make an effort to develop a well-crafted and meaningfully-presented syllabus to stimulate students' interest in the course (Canada 2013). Several scholars highlighted the importance of the syllabus as more than a binding agreement, which should be more closely integrated into teaching and learning (Fornaciari and Dean 2014).

With today's advanced web technology facilitating website creations, educators have used the web as a new delivery channel to present educational and instructional materials (Harris and Martin 2012; Otter et al. 2013). In addition to the rise of online programs and online courses, many universities have adopted a course management system, such as Blackboard or D2L (Desire to Learn), to offer coursework online. Educators have started to integrate web technology into the online classroom to increase student motivation, and some have found a positive result in terms of enhanced student experiences in the classroom (Dyer et al. 2015).

Despite the importance of online course formats, scant attention has been paid to how syllabus formats can influence student learning, especially student engagement and student intention to take a course based on the online syllabus. To fill this research gap, the current study attempts to examine how the online syllabus format affects student engagement and students' intentions to take a course. Through an experimental study, this research examines how online syllabus format (learning management system: Desire2Learn vs. instructor's personal web-based course site) interacts with the 
amount of information (more or fewer details) to affect student engagement and course-taking intentions.

\section{Literature review}

\section{Online learning}

Since the adoption of the Internet in higher education, an increasing number of colleges have begun to offer online programs and courses (Allen and Seaman 2016; Donnelly 2019; Otter et al. 2013). For 13 years, the Babson Survey Research Group conducted a series of surveys to measure the trend of online learning in U.S. higher education (Allen and Seaman 2016). The report found that student enrollments in online learning continued to grow while overall higher education enrollment declined (Allen and Seaman 2016). The report revealed that a total of 5.8 million students took at least one online course in the fall of 2014. Public universities commanded the largest portion of online students $-72.7 \%$ of undergraduate students and $38.7 \%$ of graduate students. The increasing number of students enrolling in online or web-based courses suggests that online learning has become part of the course offerings at many universities. The increase in online course offerings is also a way for college administrators to respond to recent fiscal challenges, such as shrinking education budgets and lower enrollments of traditional students (Donnelly 2019).

Against this backdrop, many empirical studies have been conducted to examine how the online syllabus is related to the quality of online course and teaching effectiveness. Van Rooyen and Dry (2015) study provided insight into how students use the online syllabus as an important learning tool to grasp the various subject concepts and guide them throughout the semester. For global learners, Lalla (2015) highlights applying low-context communication strategies, which requires explicit and direct messages, directions, and explanations, to the online course syllabus to achieve culturally inclusive pedagogical practices. Zhang (2016) found that the course syllabus in a learning management system can be positively related to their learning performance and suggested that "the syllabus is an important tool for students to get organized for the course, which in turn should be helpful for learning" (265). Gómez-Rey, Barbera, and Fernández-Navarro (2018) also demonstrated that clear syllabus with educational and detailed information can positively influence online teaching effectiveness by making student learning environment more transparent and intuitive.

\section{Online syllabus and student engagement}

In response to the increase in online course offerings, several studies have examined how online and/or web-based courses have transformed course delivery and the ways students learn. Scholars have explored several topics, including faculty's and students' perceived usefulness of technology, student learning, student engagement, and student motivation (Bonds-Raacke 2006; Dyer et al. 2015).

Dyer et al. (2015) examined the use of online technology to increase student motivation and found that an online component enhanced students' experiences in the classroom. Other scholars have also found that students' perceived usefulness of online learning management system can positively influence their learning outcome and grade performance (Liang et al. 2014; Spivey and McMillan 2013). Jones and Jones (2005) investigated students' and professors' perceptions of the use of effectiveness of Courselnfo, the web-based course management system. Their findings reported that students believed Courselnfo was a useful tool and helped improve their learning. Leung and Ivy (2003) found 
that students made use of instructor's personal course websites and perceived that course websites enhanced learning. Furthermore, the majority of the students in their study preferred the personal websites for their future courses, although they did not prefer web-only courses that eliminated class meetings.

According to DeNeui and Dodge (2006), one of the main benefits of an online learning management system is the "unfettered access to virtually anything an instructor presents in the classroom. For example, access to syllabi, course notes, interactive demonstrations, handouts, audio or videotaped lectures are all possible via this interface" (256). Similarly, Bonds-Raacke (2006) demonstrated that students' general attitudes toward instructor's personal course websites were positive and that they would regularly use certain tools of a course's websites while taking the course. A recent study also indicated that students are engaged by a course syllabus rich in graphic design and other visual elements (e.g., highlights in different colors) more than by a traditional text-oriented design, owing to the former's resemblance to typical personal websites (Ludy et al. 2016). However, no study has yet compared different versions of online syllabi in relation to student engagement. Therefore, this study proposes the following research question:

RQ 1: Will the online course management system and the instructor's personal web-based syllabus affect student engagement in a course differently?

\section{Online syllabus and course-taking intentions}

Researchers have conducted various studies to investigate students' behavioral intentions to take a course (Liaw 2008; Ludy et al. 2016; Tung and Chang 2008). Previous studies have indicated that perceived convenience and ease of use (e.g., the interface of the online course is clear and easy to understand) could increase students' behavioral intentions to take an online course (Nemati and Marcial 2009; Tung and Chang 2008). Liaw (2008) also found that perceived usefulness and satisfaction with the Blackboard e-learning system increased the learners' behavioral intention to take a course using an e-learning system. Recently, scholars have suggested that faculty need to pay special attention to design of course content in web-based courses because the multimedia presentations beyond the text-heavy materials can enhance student satisfaction as well as course-taking intention (Olliges 2017).

Studying the effects of online syllabi specifically, Grigorovici, Nam, and Russill (2003) examined whether student interactivity with an online syllabus influenced their first impressions of a course and their interest in taking the course. Using different levels of syllabus interactivity in their experiment, the authors found that higher interactivity resulted in students' positive impression of the syllabus and their interest in taking the course. Relatedly, Ludy et al. (2016) research showed that how visually appealing a syllabus, which was perceived as personal website, is could influence students' intentions to take a course, as a syllabus heavily designed with graphics and other visual elements was more effective than a text-oriented syllabus. Therefore, this study asks the following research question:

RQ 2: Will the online course management system and the instructor's personal web-based syllabus affect student course-taking intentions differently? 
Moderating role of amount of syllabus information

In terms of the amount of information, scholars have explored whether or how the syllabus level of detail or amount of information affects students' interest in or perception of the course and course instructor. Saville et al. (2010) conducted an experimental study comparing the length of the course syllabus (two pages with brief information about course objectives, textbook, course assignment, and course policies vs. six pages with detailed information about each element) and found that the longer syllabus resulted in a better impression among students of the course instructor's teaching effectiveness. In general, scholars have demonstrated that a long, detailed syllabus could be better than a short one, because students who receive a detailed syllabus receive important course information and are likely to view their instructor's teaching effectiveness positively (Fink 2012; Richmond et al. 2016). Specifically, researchers have found that a longer syllabus can help instructors communicate that they care for their students (Saville et al. 2010) in addition to stimulating positive impressions from students of their effectiveness (Harrington and Gabert-Quillen 2015; Jenkins, Bugeja, and Barber 2014).

However, other scholars have found negative effects of a longer and detailed syllabus, because students are less likely to remember the majority of syllabus content (Smith and Razzouk 1993; Thompson 2007). Fornaciari and Dean (2014) suggested that a long and detailed syllabus should change to shorter and more flexibly-constructed one, in order to optimize student learning. In addition, the results from Ekachai and Kim (2019) experimental study showed that a less detailed syllabus had a positive impact on course and course instructor impressions when it relied on graphics and other visual elements in different colors.

When it comes to student engagement/interest in a course and course-taking intentions, extant studies have not yet found consistent evidence. Saville et al.'s (2010) study showed that students who viewed a detailed syllabus were more likely to rate the teacher's qualities positively, and they were more likely to recommend the course to a friend and to take another course from the same teacher. However, Jenkins, Bugeja, and Barber (2014) did not find clear evidence as to whether those who read the detailed syllabus would like to take the course or would recommend it to others. Recently, Harrington and Gabert-Quillen (2015) examined how syllabus length and use of images impact these areas. Their experiment used three different versions of syllabi in terms of length-short (6 pages with basic information such as the course overview and textbook), medium (9 pages with detailed information about assignments and study tips), and long (15 pages with detailed information about rubric) syllabi-and indicated that students preferred a long syllabus, as it provided great detail on policies and assignments. To clarify the moderating effect of different amounts of information in an online syllabus, therefore, this study asks the following research questions:

RQ 3: Will the amount of syllabus information moderate the effects of syllabus format (online course management vs. the instructor's personal web-based syllabus) on engagement in a course?

RQ 4: Will the amount of syllabus information moderate the effects of syllabus format (online course management vs. the instructor's personal web-based syllabus) on student course-taking intentions? 


\section{Method}

\section{Study design}

For the research design, this study used a 2 (format: learning management system (D2L) or instructor's website) $\times 2$ (information amount: more or less details) experimental study with between-subjects groups. One communication course was used as a stimulus (course syllabus), as it is an elective course (International Advertising and Public Relations) and thus applies no psychological pressure in terms of taking the course as a requirement for graduation.

\section{Participants}

The total sample was $94(n=94)$ students, after a student with missing data $(n=1)$ was dropped. The participants were recruited from undergraduate communication courses at a large university in the United States Midwest. All participants volunteered to participate in the experimental study and received \$10 gift cards as compensation. Participants' ages ranged from 18-25 years old, with an average age of 20.30 years $(S D=1.33)$. Female students were $76.6 \%(n=72)$ of the sample, and male students made up $23.4 \%$ ( $n=22$ ) of the sample. In terms of ethnic makeup, $70.2 \%(n=66)$ of the students were White, $11.7 \%(n=11)$ were Hispanic/Latino, $10.6 \%(n=10)$ were Asian/Asian-American, and $7.5 \%(n=7)$ were other races (e.g., African or Native American). In terms of school year, $35.1 \%$ of participants were the seniors $(n=33), 27.7 \%$ were juniors $(n=31), 29.8 \%$ were sophomores $(n=28)$, and $7.4 \%$ were freshmen $(n=7)$.

\section{Stimulus development}

To develop the measures for the amount of syllabus information, two sessions of focus group interviews (FGIs, $N=10$ ) and a preliminary experiment $(N=21)$, were conducted to determine the design and the information amount, as well as to check the ecological validity of the course's syllabus.

Two FGIs $(N=10)$ were conducted with students enrolled in communication courses related to strategic communication (e.g., advertising and public relations). Each participant received a booklet that includes the four versions of the syllabus in random order, with each version being a unique combination of amount of information (more or less) and design (text-oriented black-and-white or visual aids and colored letters). The information and design of the course syllabus were crafted with recommended features based on previous research (e.g., Ludy et al. 2016). After reviewing the different versions, all participants in the two FGIs confirmed syllabus contents, design, and amount of information in relation to ecological validity.

In terms of design, most of FGI participants preferred the syllabus with visual aids and color fonts rather than the text-oriented black-and-white syllabus. Therefore, the final versions of syllabi for this study were designed with colored, visual images (e.g., example photos of textbook/relevant cases) and highlighted and bold letters as the online version syllabus. In terms of amount of information, two different versions-fewer or more details-were created based on the FGIs participants' suggestions. The less-detailed version syllabus only had the required information, including general course information (i.e., description, instructor name, contact information, and office hours), course goals, learning objectives, required readings/textbooks, course requirements (names of assignments and grade scales), and a course schedule. In the more-detailed version, details were added to the short version to include detailed assignment descriptions, deadlines, and course policies, including 
assignment submission, professionalism, attendance, communication, academic integrity, and other campus resources such as the counseling center and the disability center).

The final versions of the syllabi were embedded into two different online formats, the online learning management system (D2L) and an instructor's personal website created by Wix (a cloud-based web development platform). The D2L versions of the syllabus, both in short and long format, were presented in a pdf file with some visual elements such as images and colored or bolded texts. In the instructor's personal website version, the syllabus showed different tabs on the web page to indicate different syllabus elements such as course overview, requirements, and schedule, making the web page more navigable. The web page also featured the similar images and other visual elements. The first page of each type of format is provided in Appendix A.

The preliminary experiment study $(N=21)$ was a pilot study testing the online versions with different communications students from the FGI. In the preliminary experiment study, the syllabi and researcher questions were rated for clarity $(M=6.43, S D=1.03)$, understandability $(M=6.10, S D=1.45)$, and relevancy $(M=6.05, S D=1.12)$ on a 7-point Likert scale.

\section{Procedure}

To recruit undergraduate students to participate in this study, we used in-class announcements, email invitations, flyers, and social media posts to the college's social media accounts. All participants first signed a consent form. They were randomly assigned to one of the four experimental conditions, being given a link produced by a cross-combination of syllabus format (D2L or Website) and syllabus information (less or more). The participants then answered questions presented on Qualtrics measuring engagement and course-taking intentions. Demographic information-including gender, race, major, and school year-was asked at the end of the experiment. Through a pretest $(N=10)$, researchers checked the procedure (stimulus manipulation and randomization) and clarity of questions, and they confirmed that no issue was present in the study design. The main test $(N=94)$ was then conducted with the same procedure confirmed in the pretest.

\section{Measures}

All items used for each variable were adopted from previous research. The items were measured on a 7-point Likert scale ( 1 = not at all -7 = very much) and were combined into one construct for engagement and course-taking intentions.

To measure student engagement, 17 items were adopted from Schaufeli et al. (2002) scales, consisting of vigor: 6 items measuring vigor [(Cronbach's $(\alpha)=.86, M=4.77, S D=1.02)$ ] [(e.g., after reading the syllabus, I would feel strongly and vigorously about the class when I am studying or attending this class)], 5 items measuring dedication $[(\alpha=.85, M=5.27, S D=1.02)$ ] [(e.g., after reading the syllabus, my studies in this class would inspire me $)]$, and 6 items measuring absorption $[(\alpha=$ $.89, M=3.44, S D=1.11$ )] [(e.g., after reading the syllabus, I feel that time would fly when I am studying for this class)]. All dimensions were combined into one construct for engagement.

Course-taking intentions were measured by using Ludy et al. (2016) three items adapted from Saville et al. (2010) measures for Syllabus Detail and Students' Perceptions of Teacher Effectiveness $(\alpha=$ $.89, M=5.24, S D=1.27$ ) (e.g., I would like to take this course). 


\section{Results}

\section{Manipulation checks}

Each condition had almost an equal sample size, with balanced demographic characteristics (race, major, and school year) and without any significant differences at $p>.05$. To check the manipulation of the online syllabus format, the participants were asked to rate the following items with a 7-point scale ( 1 = strongly disagree, 7 = strongly agree): "the syllabus provides detailed explanation of the obligations for both instructor and student in D2L or on the website." For the first question asking about the D2L version, the mean scores of those who read the D2L version of the syllabus were $5.55(S D=1.94)$, while the mean scores of those who read the website version of the syllabus were $3.35(S D=2.47)$. The independent samples $t$-test revealed that the mean differences were statistically significant at $p<0.001$. For the second question asking about the instructor's personal website version of syllabus, the mean scores of those who read the D2L version were $4.47(S D=2.24)$, while the mean scores of those who read the website version were $6.04(S D=1.59)$. The differences were statistically significant at $p<0.001$ according to an intendent samples $t$-test.

The manipulation for syllabus information (less or more) was checked through an independent samples $t$-test. The results indicated that those who received the more-detailed version $(M=5.77, S D=1.82)$ were more likely to report detailed explanation of obligations for both instructor and student (i.e., course policies such as late assignments) than those who received the less detailed version $(M=4.71, S D=2.23), \mathrm{t}(92)=2.51, p=.01$.

\section{Answering research questions}

RQ1 asked how a syllabus on the course management system versus on the course website would affect student engagement differently, and RQ 3 asked how different amounts of syllabus information would moderate the effects of syllabus format on student engagement in the course. A two-way ANOVA revealed a significant main effect of format on engagement, $F(1,90)=4.10, p=0.04, \eta^{2}=3.14$. Those who received the course syllabus through an instructor's course website $(M=4.68, S D=0.87)$ were more likely to engage in the course than those who received it through $\mathrm{D} 2 \mathrm{~L}(M=4.31, S D=0.87)$. However, neither a significant main effect of the information amount nor interaction effects of format and information amount were found to have an impact on student engagement (see Tables 1 and 2). 
Table 1. Univariate analysis results for student engagement and course taking intentions.

\begin{tabular}{|l|l|l|l|l|}
\hline & Dependent variables & Mean square & $\boldsymbol{F}$ - value & Partial Eta squared $\boldsymbol{\eta}^{\mathbf{2}}$ \\
\hline Syllabus format & Student engagement & 3.14 & $4.11^{*}$ & .04 \\
\hline & Course taking intentions & 9.61 & $6.26^{*}$ & .07 \\
\hline Syllabus information amount & Student engagement & 0.34 & 0.44 & .01 \\
\hline & Course taking intentions & 1.18 & 0.77 & .01 \\
\hline Syllabus format X syllabus information amount & Student engagement & 0.30 & 0.40 & .00 \\
\hline & Course taking intentions & 1.05 & 0.69 & .01 \\
\hline
\end{tabular}

Note. ${ }^{* * *} p<.001,{ }^{*} p<.05$

Table 2. Mean differences of syllabus format and information amount for student engagement and course taking intentions.

\begin{tabular}{|l|l|l|l|l|l|}
\hline & & Student engagement & & Course taking intentions & \\
\hline & & Mean & Standard deviation & Mean & Standard deviation \\
\hline Syllabus format & D2L & $4.31 \mathrm{a}$ & 0.87 & $4.92 \mathrm{a}$ & 1.40 \\
\hline & Instructor's website & $4.68 \mathrm{~b}$ & 0.87 & $5.57 \mathrm{~b}$ & 1.04 \\
\hline Syllabus information & More detailed & 4.56 & 0.91 & 5.12 & 1.24 \\
\hline & Less detailed & 4.42 & 0.85 & 5.37 & 1.31 \\
\hline
\end{tabular}

Note. D2L: Desire2Learning (online learning management program). Means indexed by subscripts are significantly different, $p<.05$. 
In terms of course-taking intentions, RQ2 asked how the online course management system versus the instructor's personal web-based syllabus would affect student course-taking intentions differently, and RQ4 asked how the syllabus information amount would moderate the effects of syllabus format on students' course-taking intentions. A two-way ANOVA revealed a significant main effect of format on course-taking intentions, $F(1,90)=6.26, p=0.02, \eta^{2}=0.07$. Participants who viewed the syllabus on the instructor's website $(M=5.57, S D=1.04)$ were more likely to intend to take or recommend the course than those who viewed the $\mathrm{D} 2 \mathrm{~L}$ version $(M=4.92, S D=1.40)$. However, neither a significant main effect of the information amount nor interaction effects of format and information amount were found to impact course-taking intentions (see Tables 1 and 2).

\section{Discussion}

This study explored how different online syllabus formats affect students' engagement and their intentions to take a course. The study also examined how the amount of information in the online syllabus affects students' engagement and their intentions to take the course. The study found that those who read the syllabus on the instructor's website were more likely to engage with and to intend to take the course than those who read the syllabus on D2L. This could be due to the fact that a course website can incorporate graphics, audio, video clips, real-time (synchronous) communication, interactive assignments, and asynchronous communication in the web presence of a course (Leung and Ivy 2003). The participants may have perceived the instructor's website syllabus more technologynested instructional one than the D2L version's syllabus. Lumpkin, Achen, and Dodd (2015) suggested that "technology-nested strategies engage students actively in their learning and help reinforce information previously presented, especially as a change of pace punctuating traditional lectures" (123). The syllabus on D2L was downloadable. The downloaded file (syllabus) did neither support going online nor include such diverse online features that could be positively associated with student engagement (Zhang 2016).

The findings of the effects of level of detail are inconsistent with previous studies (e.g., Jenkins, Bugeja, and Barber 2014; Harrington and Gabert-Quillen 2015), as the present study suggested that the amount of information provided in either format of the online syllabus did not seem to influence either students' engagement or their intention to take the course. This could potentially be influenced by the unique features of the website (such as tabs that separate sections of the syllabus), which might not make the detail level of the syllabus detectable.

\section{Implications}

The results of this study provide some insights into how instructors can engage and attract their students through online course syllabi. The findings suggest the importance of the online format to student engagement and to their intention to take a course. Findings from this study indicates that providing students with a more interactive, web-based syllabus might be an effective way to foster student engagement, thus generating an intention to take the course or recommend the course to others. While instructors have focused on course content, assignments, and schedule in their traditional syllabi, the results of the current study suggest that both instructors and students could benefit from online, the instructor's personal web-based syllabi. 
However, one pragmatic question is whether instructors should abandon their university's course management system to create a course website to deliver their course materials. Furthermore, resources like time availability and instructional designers are essential to making a course website successful. Instructors who have developed course websites have used web-publishing software programs such as WordPress, Weebly, Wix, or even some specialized hypertext markup language (HTML) authoring programs. Instructors may need to learn more about web design or get help from designers, particularly for more sophisticated websites that require HTML programing. A newer, more advanced learning management system (such as Canvas) that includes responsive and virtual elements might give instructors an alternative option, where they can integrate visual and online features into their course without having to develop a course website from scratch.

Relatedly, this study provides empirical evidence for suggestions from previous research that emphasized higher education institutions' support of professional developments for online instructors as well as adequate support for technical issues (Kebritchi, Lipschuetz, and Santiague 2017; Lion and Stark 2010). Specifically, Kebritchi, Lipschuetz, and Santiague (2017) suggested the importance of the support of educational institutions to actively improve the quality of online education.

\section{Limitations and suggestions for future research}

This study has some limitations that should be addressed in future research. In this study, many more participants were female (76.6\%) than male. Research has found that students learn differently based on gender (Johnson 2011): Johnson (2011) found that Internet use may benefit females more than males, due to gender differences in orientation to the Internet (i.e., accomplishment versus recreation). Therefore, because the number of male participants was too small to establish statistical significance, future research could examine the gender variable and compare differences between male and female students on student engagement and motivation.

In addition, some educational scholars have examined the roles of students' learning styles and student learning (Fendler, Ruff, and Shrikhande 2016; Tan et al. 2018). Fendler, Ruff, and Shrikhande (2016) found that verbal learners, who prefer to see pictures, diagrams, flow charts, and demonstrations, are more likely to succeed in an online class than other types of learners (e.g., verbal learners who prefer to see written and spoken explanation). Tan et al. (2018) also demonstrated that students' different learning styles were strongly associated with online learning. They contended that students who prefer hands-on activities such as games and simulations were more likely to maintain their intention to use online learning tools. Therefore, it would be worthwhile for future research, to compare the use of a course website among students with different learning styles.

Furthermore, qualitative research should be conducted in future research to clarify which features of the instructor's website syllabus had the most significant and meaningful effects. In this study, variations within the website features were not examined. Focus groups or in-depth interviews would be useful to provide more specific/clear evidence and to explore how different features of the instructor's website affect student engagement and course-taking intentions. 


\section{References}

Agrawal, N. 2020. "CSU Plans to Cancel Most In-Person Classes and Go Online This Fall, Chancellors Says." Los Angeles Times, April 8. https://www.latimes.com/california/story/2020-05-12/coronavirusreopening-csu-fall-online-classes

Allen, I. E., and J. Seaman. 2016. "Online Report Card: Tracking Online Education in the United States." Babson Survey Research Group and Quahong Research Group, LLC. https://files.eric.ed.gov/fulltext/ED572777.pdf.

Bart, M. 2011. "Report Uncovers Hidden Costs of Managing Syllabi." Faculty Focus. https://www.facultyfocus.com/articles/course-design-ideas/report-uncovers-the-hiddencosts-of-managing-syllabi/.

Bonds-Raacke, J. M. 2006. "Students' Attitudes toward the Introduction of a Course Website." Journal of Instructional Psychology 33 (4):251-5.

Canada, M. 2013. "The Syllabus: A Place to Engage Students' Egos." New Directions for Teaching and Learning 2013 (135):37-42. doi: 10.1002/tl.20062.

DeNeui, D. L., and T. L. Dodge. 2006. "Asynchronous Learning Networks and Student Outcomes: The Utility of Online Learning Components in Hybrid Courses." Journal of Instructional Psychology 33 (4):256-9.

Donnelly, M. 2019. "Free and Open Source Software in Education." Salem Press Encyclopedia. Pasadena: Salem Press.

Dyer, T., E. Larson, J. Steele, and R. Holbec. 2015. "Integrating Technology into the Online Classroom through Collaboration to Increase Student Motivation." Journal of Instructional Research 4 (2015):126-33. doi: 10.9743/JIR.2015.16.

Ekachai, D., and Y. Kim. 2019. "Does Your PR Course Syllabus Excite, Intrigue, and Motivate Students to Learn? Syllabus Designs and Student Impressions on the PR Course and the Course Instructor." Journal of Public Relations Education 5 (1):101-33.

Fendler, R. J., C. Ruff, and M. Shrikhande. 2016. "Evaluating Characteristics of Top and Bottom Performance: Online versus in-Class." American Journal of Distance Education 30 (2):109-20. doi: 10.1080/08923647.2016.1153350.

Fink, S. B. 2012. "The Many Purposes of Course Syllabi: Which Are Essential and Useful." Syllabus 1 (1):112. https://www.scholarlyexchange.org/ojs/index.php/TS/article/view/10147/PDF.

Fornaciari, C. J., and K. L. Dean. 2014. "The 21st-Century Syllabus: From Pedagogy to Andragogy." Journal of Management Education 38 (5):701-23. doi: 10.1177/1052562913504763.

Gómez-Rey, P., E. Barbera, and F. Fernández-Navarro. 2018. "Students' Perceptions about Online Teaching Effectiveness: A Bottom-Up Approach for Identifying Online Instructors' Roles." Australasian Journal of Educational Technology 34 (1):116-30. doi: 10.14742/ajet.3437.

Grigorovici, D., S. Nam, and C. Russill. 2003. "The Effects of Online Syllabus Interactivity on Students' Perception of the Course and Instructor." The Internet and Higher Education 6 (1):41-52. doi: 10.1016/S10967516(02)00163-X.

Harrington, C. M., and C. A. Gabert-Quillen. 2015. "Syllabus Length and Use of Images: An Empirical Investigation of Student Perceptions." Scholarship of Teaching and Learning in Psychology 1 (3):235-43. doi: $10.1037 /$ stl0000040.

Harris, H. S., and E. W. Martin. 2012. "Student Motivations for Choosing Online Classes." International Journal for the Scholarship of Teaching and Learning 6 (2):1-8. doi: 10.20429/ijsotl.2012.060211.

Jenkins, J. S., A. D. Bugeja, and L. K. Barber. 2014. "More Content or More Policy? A Closer Look at Syllabus Detail, Instructor Gender, and Perceptions of Instructor Effectiveness." College Teaching 62 (4):129-35. doi: 10.1080/87567555.2014.935700.

Johnson, G. M. 2011. "Internet Activities and Developmental Predictors: Gender Differences among Digital Natives." Journal of Interactive Online Learning 10 (2):64-76. 
Jones, G. H., and B. H. Jones. 2005. "A Comparison of Teacher and Student Attitudes Concerning Use and Effectiveness of Web-Based Course Management Software." Educational Technology \& Society 8 (2):125-35. doi: 10.2307/jeductechsoci.8.2.125.

Kebritchi, M., A. Lipschuetz, and L. Santiague. 2017. "Issues and Challenges for Teaching Successful Online Courses in Higher Education: A Literature Review." Journal of Educational Technology Systems 46 (1):429. doi: 10.1177/0047239516661713.

Lalla, S. 2015. "Practicing Low-Context Communication Strategies in Online Course Design for International Students Studying in the U.S." Proceedings of the 2015 International Conference on E-Learning, 199202.

Leung, Y.-F., and M. I. Ivy. 2003. "How Useful Are Course Websites? A Study of Students' Perceptions." The Journal of Hospitality Leisure Sport and Tourism 2 (2):15-25. doi: 10.3794/johlste.22.38.

Liang, D., J. Jia, X. Wu, J. Miao, and A. Wang. 2014. "Analysis of Learners' Behaviors and Learning Outcomes in a Massive Open Online Course." Knowledge Management \& E-Learning 6 (3):281-98.

Liaw, S.-S. 2008. "Investigating Students' Perceived Satisfaction, Behavioral Intention, and Effectiveness of ELearning: A Case Study of the Blackboard System." Computers \& Education 51 (2):864-73. doi: 10.1016/j.compedu.2007.09.005.

Lion, R. W., and G. Stark. 2010. "A Glance at Institutional Support for Faculty Teaching in an Online Learning Environment." Educause Quarterly 33 (3):23-39.

Ludy, M.-J., T. Brackenbury, J. W. Folkins, S. H. Peet, S. J. Langendorfer, and K. Beining. 2016. "Student Impressions of Syllabus Design: Engaging versus Contractual Syllabus." International Journal for the Scholarship of Teaching and Learning 10 (2):1-23. doi: 10.20429/ijsotl.2016.100206.

Lumpkin, A., Achen, R. M. R. K. Dodd, and R. K. 2015. “Using Technology-Nested Instructional Strategies to Enhance Student Learning." InSight: A Journal of Scholarly Teaching 10:114-25. doi: 10.46504/10201509lu.

Nemati, H., and T. Marcial. 2009. "Factors Influencing Students Intention to Take Web-Based Courses in a College Environment." International Journal of Information \& Communication Technology Education 5 (3):83-93.

Olliges, R. 2017. "Using a Learning Styles Inventory to Examine Student Satisfaction with Web-Based Instruction: A 15-Year Study of One Professor's Web-Based Course Instruction." InSight: A Journal of Scholarly Teaching 12:120-31. doi: 10.46504/12201707ol.

Otter, R. R., S. Seipel, T. Graeff, B. Alexander, C. Boraiko, J. Gray, K. Petersen, and K. Sadler. 2013. "Comparing Student and Faculty Perceptions of Online and Traditional Courses." The Internet and Higher Education 19 (2013):27-35. doi: 10.1016/j.iheduc.2013.08.001.

Richmond, A. S., J. M. Slattery, N. Mitchell, R. K. Morgan, and J. Becknell. 2016. "Can a Learner-Centered Syllabus Change Students' Perceptions of Student-Professor Rapport and Master Teacher Behaviors?" Scholarship of Teaching and Learning in Psychology 2 (3):159-68. doi: 10.1037/stl0000066.

Saville, B. K. T E., Zinn, A. R. Brown, and K. A. Marchuk. 2010. "Syllabus Detail and Students' Perceptions of Teacher Effectiveness." Teaching of Psychology 37 (3):186-9. doi: 10.1080/00986283.2010.488523.

Schaufeli, W. B., M. Salanova, V. González-Romá, and A. B. Bakker. 2002. "The Measurement of Engagement and Burnout: A Two Sample Confirmatory Factor Analytic Approach." Journal of Happiness Studies 3 (1):7192. doi: 10.1023/A:1015630930326.

Smith, M. F., and N. Y. Razzouk. 1993. "Improving Classroom Communication: The Case of the Course Syllabus." Journal of Education for Business 68 (4):215-21. doi: 10.1080/08832323.1993.10117616.

Spivey, M. F., and J. J. McMillan. 2013. "Using the Blackboard Course Management System to Analyze Student Effort and Performance." Journal of Financial Education 39 (1/2):19-28.

Tan, S. Z., N. Hassim, S. Y. Jayasainan, and P. C. K. Gan. 2018. "Effects of Task-Technology Fit and Learning Styles on Continuance Intention to Use e-Learning App." Proceedings of the 2018 17th European Conference on E-Learning, 539-46.

Thompson, B. 2007. "The Syllabus as a Communication Document: Constructing and Presenting the Syllabus." Communication Education 56 (1):54-71. doi: 10.1080/03634520601011575. 
Tung, F.-C., and S.-C. Chang. 2008. "Nursing Students' Behavioral Intention to Use Online Courses: A Questionnaire Survey." International Journal of Nursing Studies 45 (9):1299-309. doi: 10.1016/j.ijnurstu.2007.09.011.

Van Rooyen, A., and R. Dry. 2015. "Law Students' Perceptions of Online Self-Assessment Assignments in an Accounting Module." Proceedings of the 2015 International Conference on E-Learning, 315-22.

Zhang, X. 2016. "An Analysis of Online Students' Behaviors on Course Sites and the Effects on Learning Performance: A Case Study of Four LIS Online Classes." Journal of Education for Library and Information Science 57 (4):255-70. doi: 10.3138/jelis.57.4.255. 